\title{
Karlovy Vary 2007
}

\author{
By Ron Holloway
}

Fall 2007 Issue of KINEMA

\section{$42^{\text {nd }}$ KARLOVY VARY INTERNATIONAL FILM FESTIVAL}

Records were broken at the $42^{\text {nd }}$ Karlovy Vary International Film Festival (29 June to 7 July 2007). Festival president Jiř́ Bartoška and artistic director Eva Zaoralová welcomed 12,000 accredited guests, 500 more than in the previous year. Another record was passed when 580 journalists registered for KVIFF, 300 more than in 2006. Another record was passed when 580 journalists registered for KVIFF, 300 more than in 2006. And who really knows how many students and young cineastes flocked to Karlovy Vary from across the Czech and Slovak Republics, many of them sleeping in the park in tents provided by the festival and sometimes under the stairs of the Hotel Thermal when it rained. Even a children's play pen was added in the Thermal Hotel, the festival headquarters. With lines forming before the box offices as early at seven in the morning, the only problem young cineastes had was picking four films to view with a Participation ID Pass - over 10,000 issued in 2007! - after which they were often given permission to sit on the floor at any one of the festival's 13 venues.

Hollywood stars, too, have taken a liking to the spa festival. Renee Zellweger was on hand for the screening of Chris Noonan's Miss Potter (USA), in which she plays British author-illustrator Beatrix Potter (18661943), the creator of the children's book The Tale of Peter Rabbit (published in 1902). Zellweger returned the next day to hand veteran Czech puppet-and-animation filmmaker Bretislav Pojar a Crystal Globe for "outstanding artistic contribution to world cinema." Another honorary globe was handed to Danny DeVito, whose appearance in Jake Paltrow's comedy The Good Night closed the festival. As warmly as these stars were received by the festival audience, nothing could match the adulation showered upon the "man of the hour" on closing night. A standing ovation greeted the presence of Václav Havel, formerly the Czech President, who is best known abroad as one of the initiators of the Charta 77 human rights declaration, for which he had spent five years in prison under communist rule. The writer-dramatist, whose father had built Barrandov Film Studio in pre-war days, was also instrumental in bringing his friend Miloš Forman back to Prague to help revitalize the Czech film industry in the wake of the Velvet Revolution. No wonder he's a legend in his own time!

According to program director Juliette Zacharová, nine world premieres surfaced among the 250 films screened - another sure sign of Karlovy Vary's increasingly favoured status among big time film festivals. Today, Karlovy Vary serves as a welcomed respite from those icy winters at the Berlinale and the waiting lines at Cannes. Furthermore, since December of 1989, when the Velvet Revolution swept through Czechoslovakia, the city's historical sites - hotels, villas, baths, monuments - have all been restored to their pristine glory. Among these restorations is the splendid rococo Divadlo Theatre, built in 1886 and opened back then with a performance of Mozart's The Wedding of Figaro. Indeed, the Divadlo is an appropriate festival venue for "Treasures from the National Film Archive." This year, Fritz Lang's two-part silent sinister classic, The Spiders I (The Golden Lake) \& II (The Diamond Ship, 1919-20), was programmed with live orchestral accompaniment.

As press conferences go, nothing surpassed the give-and-take at the "New Hollywood" gathering. To begin with, not many in the young crowd had ever seen any of the eight films in the retrospective. But even festival veterans lined up for tickets to Peter Bogdanovich's The Last Picture Show (1971), Hal Ashby's Harold and Maude (1971), Monte Hellman's Two-Lane Blacktop (1971), George Lucas's American Graffiti (1973), Terrence Malick's Badlands (1973), Martin Scorsese's Mean Streets (1973), Francis Ford Coppola's The Conversation (1974), and Steven Spielberg's The Sugarland Express (1974). Cybill Shepherd at the press session talked about her "Svengali" relationship with Peter Bogdanovich. Bud Cort remembered how nervous he was while working with Ruth Gordon on Harold and Maude. And Monte Hellman reminisced on trying to direct actor Sam Peckinpah in China 9, Liberty 37 (1978). In passing, some jokes were made about the visible wear-and-tear on the prints found in the Czech Film Archive. But for some die-hard film devotees scratchy old prints made the viewing experience all the more enjoyable! 
Last year, Karlovy Vary hit pay dirt by inviting the prestigious Sundance Film Festival to present past award winners, both features and documentaries, from the festival archive. This year, Karlovy Vary linked its fortunes to the Sochi Open Russian Film Festival. Just a few weeks after Alexei Popogrebsky's Prostyje veshchi (Simple Things) was awarded an armful of prizes at Sochi, the film garnered several citations at Karlovy Vary. The Best Actor Award went to Sergei Puskepalis, with an additional Special Mention to noted stage personality Leonid Bronevoy. A poignant drama about a low-paid hospital anaesthetist (Puskepalis), who lives with his wife and teenaged daughter in a crowded communal apartment, Simple Things takes on colour and interest when the beleaguered husband and father accepts a side job caring for a crusty old actor (Bronevoy) in the last stages of his cancer ailment. Their reluctant affiliation eventually opens up unexpected vistas. Simple Things also won the FIPRESCI (International Critics) Award and the Ecumenical Award.

Karlovy Vary thrives on a bundle of awards and juries. Besides the top liner International Jury, headed by Variety editor Peter Bart, noted personalities were summoned to judge the competitions in the Documentary and East of the West (Central and Eastern European Films) sections. These, in addition to the non-statuary juries: FIPRESCI, Ecumenical, Netpac (Network for Promotion of Asian Cinema), FICC (Film Clubs), Europa Cinemas Label (European Exhibitors), Independent Camera (Forum of Independents), and Právo (Audience Prize). The Netpac Jury, headed by Philip Cheah of the Singapore film festival, had to consider 38 films from the Near and Far East, entries scattered across nearly all of Karlovy Vary's 20 non-competitive sections: Open Eyes, Horizons, Another View, Forum of Independents, Variety Critics' Choice, Czech Films, Midnight Screenings, and Shochiku Nouvelle Vague. The award went to Eran Kolirin's Bikur hatizmoret (The Band's Visit, Israel-France), an amusing tongue-in-cheek tale about an Egyptian ceremonial band lost on the byways of Israel.

The Crystal Globe, KVIFF's Grand Prix, was awarded to Baltasar Kormakur's Myrin (Jar City, IcelandGermany). A film noir crime thriller based on a best-seller, Jar City had already won four Icelandic Edda Awards and had broken home box office records before arriving at Karlovy Vary. Pegged to parallel stories, the thriller features a loner detective on a murder case with monkeys on his own back (his daughter is a drug addict) and a genetic scientist researching the causes behind his daughter's mysterious brain illness (maybe tied to the death of a four-year-old girl 30 years ago). The film was also awarded the FICC Prize.

Unfortunately, one exceptional film, reportedly favoured by the KVIFF selection committee, could not be programmed in the Competition. Because Khoonbazi (Mainline, Iran), co-directed by Rakhsham BaniEtemad and Mohsen Abdolvalab, had previously been shown at Toronto, it ended up in the Horizons section instead. The story of a mother's painful ordeal in coping with her daughter's drug addiction, Mainline is the first film in Iran to deal specifically with that taboo theme among the young. It features Baran Kosari, Rakhsham Bani-Etemad's daughter, in the role of Sara, a middle-class bride-to-be who knows she needs help but keeps falling back into her old ways. A stellar performance in a spellbinding and agonizing film shot mostly on the streets of Tehran.

The Czech entry in the competition, Jan Svěrák's Vratné láhve (Empties, Czech Republic-Denmark-UK), stars the director's father in a light comedy. Zdeněk Svěrák, who had written the script to fit his character, plays a cantankerous senior citizen who throws his teaching career overboard to take a simple job in a supermarket behind a counter for returnable bottles - the "empties" in the title. There, positioned at a quaint crossway of life, he finds a way to solve most of the problems of customers and colleagues without realizing that he has pretty much made a mess of his own life - to say nothing of overlooking the needs of his long-suffering wife and divorced daughter, who has come home to roost. Besides being voted the Právo Audience Prize, Empties also merited for Zdeněk Svěrák the screenplay award.

The prize for Best Long Documentary (over 30 minutes) was awarded to Lucie Králová's Ztracená dovolená (Lost Holiday, Czech Republic). Two years in the making by a student at the Prague Film School (FAMU), Lost Holiday unfolds like an investigative detective story. The tale begins back in 2001, when a suitcase was found in Sweden that contained 22 rolls of negative film that chronicle in 756 photographs the journey of seven unidentified Asians on a trip through Europe. Eventually, with the help of Sinologists and tourist agencies, Králová was able to determine that the group came from China and that its leader was probably a provincial government official. Also, judging from locations in the background, the group had journeyed from northern Germany to Norway. This neatly reconstructed dossier fascinates, particularly because of 
how and where the photos were taken, their style of dress, and the interaction among the persons in the entourage. Finally, since photo identification has yet to be determined, Lucie Králová's next stop as a researching documentarist will be China.

A Special Mention was given to Andrei Paounov's Problemat s komarite I drugi istorii (The Mosquito Problem and Other Stories, Bulgaria-Germany-USA). Filmed in Belene on the Danube, where giant mosquitos (nicknamed "zanzar" for their nerve-racking buzz) torment the population, extermination trucks regularly fumigate the streets on humid summer days. As for the "other stories" in the title, one proves embarrassing for the town officials - for Belene used to be the site of a forced labour camp under communist rule, whose superintendent later went on to become the town's mayor when democracy was installed. Other characters in Paounov's delightful Mosquito Problem and Other Stories are colourful in an absurd vein. A Cuban worker was stranded here when plans for a nuclear plant were abandoned. An Italian priest cares for a small flock of elderly parishioners. A piano tuner confesses his love for both Chopin and boogie-woogie. And a dance instructor visits the town on occasion to help break the monotony of the place.

Two renown documentarists were singled out for citations in the under 30 minute category. Sergei Loznitsa's Artel (Russia), awarded Best Short Documentary, was filmed during an ice-cold winter at a frozen lake near the White Sea. The "artel" in the title refers to a communal fishing enterprize still practised in Russia. Nowadays, however, when four young fishermen have (literally) to saw their through the ice to drop their nets, their struggle constitutes not only a traditional way of life, but it also hints of a hard-won livelihood as well. Loznitsa's long takes and use of black-and-white photography adds a poetic dimension to the documentary. Laila Pakalnina's Teodors (Theodore, Latvia) also scores as a quiet meditation on the meaning of life. In a Latvian village an octogenarian peddles his bicycle every morning to a bus stop, where he shares the silence of other old-timer as they watch the day slowly pass by.

Ognjen Svilicic's Armin (Croatia-Germany-Bosnia-Herzegovina) was awarded the First Prize in the East of the West Competition. In this tragicomedy, remarkable for its subtle social and political overtones, a father journeys with his 14-year-old son from a village in Herzegovina to Zagreb to help him fulfill his dream - to act and perform with his accordion in an international movie. The German film director, however, is more interested in the father's experiences as an eyewitness to tragic events during the war years. It's what the media feeds on.

Several entries in the East of the West competition heralded the revival of national cinemas in the "CentEast" region. Stanislaw Mucha's Hope (Poland-Germany, 2007), for instance, finally completes the Dante triptych - Heaven, Hell, Purgatory - that was originally outlined for international co-production by the late Krzysztof Kielowski and his screenwriter Krzysztof Piesiewicz. Following Kielowski's death, the screenplays were passed on to other filmmakers. In Tom Tykwer's Heaven (Germany-USA, 2002), an English teacher in Turin (Cate Blanchett) unintentionally commits an act of terror and is rescued from her fate by the son of the former police superintendent. In Danis Tanovic's L'Enfer (Hell, France-Italy-Belgium-Japan, 2005), three sisters (Emmanuelle Béart, Karin Viard, Marie Gillain) relive their traumatic childhood by virtue of a shared secret. And now in Stanislaw Mucha's Hope an idealistic young man (Rafal Fudalej) witnesses the theft of a rare painting from a Warsaw church, whereupon he resorts to blackmail to have the treasure turned to its rightful place. Hopefully, this film triptych will surface in the future on the festival circuit if only to determine how faithfully the three directors have explored the modern-day implications of moral unrest in Dante's classic, The Divine Comedy.

\section{References}

\section{AWARDS}

\section{International Competition}

Crystal Globe - Grand Prix

Myrin (Jar City, Iceland-Germany), dir Baltasar Kormakur 
Special Jury Prize

Lucky Miles (Australia), dir Michael James Rowland

Best Director

Bard Breien, Kunsten a tenke negativt (The Art of Negative Thinking, Norway)

Best Actress

Elvira Mínguez, Pudor (Spain), dir Tristran Ulloa, David Ulloa

Best Actor

Sergei Puskepalis, Prostyje veshchi (Simple Things, Russia), dir Alexei Popogrebsky

Special Mention - ex aequo

Leonid Bronevoy, Prostyje veshchi (Simple Things, Russia), dir Alexei Popogrebsky

Zdeněk Svěrák, for script Vratné láhve (Empties, Czech Republic), dir Jan Svěrák

\section{Documentary Competition}

Best Long Documentary (over 30 min)

Ztracená dovolená (Lost Holiday, Czech Republic), dir Lucie Králová

Special Mention

Problemat s komarite I drugi istorii (The Mosquito Problem and Other Stories, Bulgaria), dir Andrei Paounov

Best Short Documentary (under $30 \mathrm{~min}$ )

Artel (Russia), dir Sergei Loznitsa

Special Mention

Teodors (Theodore, Latvia), dir Laila Pakalnina

\section{East of the West Competition}

Best Film

Armin (Croatia-Germany-Bosnia-Herzegovina), dir Ognjen Svilcić

Special Mention

Klass (The Class, Estonia), dir Ilmar Raag

\section{Non-Statutory Awards}

International Critics (FIPRESCI) Prize

Prostyje veshchi (Simple Things, Russia), dir Alexei Popogrebsky

Ecumenical Prize

Prostyje veshchi (Simple Things, Russia), dir Alexei Popogrebsky

Special Mention

Dialogue avec mon jardiner (Conversation with My Gardiner, France), dir Jean Becker

Don Quixote Prize (FICC - International Federation of Film Clubs)

Myrin (Jar City, Iceland-Germany), dir Baltasar Kormakur

Netpac Jury - Network for the Promotion of Asian Cinema

Bikur hatizmoret (The Band's Visit, Israel-France), dir Eran Kolirin

Czech Television Award - Independent Camera Prize - Forum of Independents

Pingpong (Germany), dir Matthias Luthardt

Europa Cinemas Label Award - Main Competition and East of the West

Klass (The Class, Estonia), dir Ilmar Raag

Právo Audience Award

Vratné láhve (Empties, Czech Republic), dir Jan Svěrák 
Awards for Outstanding Artistic Contribution to World Cinema

Břetislav Pojar, Czech Republic

Danny DeVito, USA

\section{Author Information}

Ron HOLLOWAY (1933-2009) was an American critic, film historian, filmmaker and correspondent who adopted Europe as his home in the early fifties and spent much of his life in Berlin. He was an expert on the study of German cinema and against all odds produced, with his wife Dorothea, the journal German Film, keeping us up-to-date with the work of directors, producers and writers and the showing of German films around the world.

In 2007, Ron Holloway and his wife were awarded the Berlinale Camera Award. Ron also received the Bundesverdienstkreuz (German Cross of Merit), Polish Rings, Cannes Gold Medaille, the American Cinema Foundation Award, the Diploma for Support of Russian Cinema and an honorary award from the German Film Critics' Association.

Ron was also a valued contributor to Kinema for the past fifteen years. 